\title{
Accounting Harmonization for SME-S in Europe: Some Remarks on IFRS for SME-S and Empirical Evidences
}

\section{Maria-Gabriella Baldarelli, Paola Demartini, Lorena Mosnja-Skare \& Paola Paoloni}

To cite this article: Maria-Gabriella Baldarelli, Paola Demartini, Lorena Mosnja-Skare \& Paola Paoloni (2012) Accounting Harmonization for SME-S in Europe: Some Remarks on IFRS for SME-S and Empirical Evidences, Economic Research-Ekonomska Istraživanja, 25:sup1, 1-26, DOI: 10.1080/1331677X.2012.11517554

To link to this article: http://dx.doi.org/10.1080/1331677X.2012.11517554

$$
\text { (c) } 2012 \text { Economic Research }
$$

\section{曲 Published online: 09 Nov 2015.}

Submit your article to this journal ๔

山 Article views: 38

Q View related articles ¿ 


\title{
ACCOUNTING HARMONIZATION FOR SME-S IN EUROPE: SOME REMARKS ON IFRS FOR SME-S AND EMPIRICAL EVIDENCES
}

\author{
Maria-Gabriella Baldarelli* ${ }^{*}$ Paola Demartini ${ }^{\dagger}$ \\ Lorena Mosnja-Skare ${ }^{\ddagger} \quad$ Paola Paoloni ${ }^{\S}$
}

Keywords: accounting standards, SMEs, harmonization, IFRS, $I A S B, C F R S$

JEL:

\begin{abstract}
The debate on accounting truth is an old problem (Briloff, 1979) and it is at present more and more important in harmonization process, especially involving small- and medium-sized enterprises (SMEs). Their users' needs regarding the extents and type of accounting information as well as the costs of their providing are widely discussed as the arguments for differential reporting for SMEs, although there is still more literature
\end{abstract}

*University of Bologna, Via Angherà, 22, Rimini-Italy, Phone: 00390541/434124, E-Mail address: maria.baldarelli@unibo.it

†University of Roma3, Via Silvio D’Amico, 77 Rome -Italy, Phone: 00393394166228, EMail address: pdemartini@uniroma3.it

$\ddagger$ Juraj Dobrila University of Pula, P. Preradovica, 1 Pula- Croatia, Phone: 0038598898180 , E-mail address: lmosnja@efpu.hr

$\S$ UNISU (Internet Human Sciences University), Rome-Italy, Phone: 0039800.98.73.73, Email address: paola.paoloni@unisu.it 
focusing on financial reporting of large enterprises. The standards setters try to decrease the reporting burden for SMEs, keeping the relevant information for their reports users, while considering harmonization goals in the same time. In such an attempt, the International Accounting Standards Board (IASB) issued an International Financial Reporting Standard (IFRS) designed for use by small and medium-sized entities (SMEs) the $g^{\text {th }}$ of July 2009, however some national European standard-setters seem not to be keen to introduce them. The aim of our paper is to analyze, the attempts and difficulties to reach all these goals in the same time and to implement the IFRS for SMEs, such as drawn by the IASB, in the European countries. Croatian experiences presented, running from International Accounting Standards (IAS) implementation as obligatory for all the companies, towards Croatian Financial Reporting Standards (CFRS) introduction for SMEs, represent an interesting experiment in the European context.

\section{INTRODUCTION}

Small and medium-sized enterprises (SMEs) represent the sector of real economic power and are the largest employers in Europe (Marchini, 2002; Hutchinson and Ray, 1986; Mc Mahon et al. 1994; Mc Mahon, 1999; Kirby et al. 1998; Collis and Jarvis, 2000).

International Accounting Standards Board (IASB) issued an International Financial Reporting Standard (IFRS) designed for use SMEs on the $9^{\text {th }}$ of July 2009. The standard is a result of a five-year development process with extensive consultation of SMEs worldwide, however some national European standardsetters seem not to be keen to introduce them, as a legal requirement or, even as an optional choice for the vast majority of their SMEs.

The aim of our paper is to give an overview across the IASB's project on IFRS for SMEs and its reflections in Europe, stressing the difficulties to implement the IFRS for SMEs, such as drawn by the IASB, in the European countries and also to present the Croatian experiences of replacing the international by national accounting standards for SMEs.

Maria-Gabriella Baldarelli, Paola Demartini, Lorena Mosnja-Skare, Paola Paoloni- ACCOUNTING HARMONIZATION FOR SME-S IN EUROPE: SOME REMARKS ON IFRS FOR SME-S AND EMPIRICAL EVIDENCES 


\section{ARGUMENTS FOR AND AGAINST DIF- FERENTIAL REPORTING FOR SMEs}

In a debate upon differential reporting and IFRS versus local Generally Accepted Accounting Principles (GAAP) implementation, Verlee (2005) systemized the arguments for complete harmonization in comparison with differential local GAAP implementation:

- higher quality (Niskanen et al., 2000; Auer's, 1996; Ashbaugh and Pincus, 2000; Leuz and Verrecchia, 2000; Ball et al., 2000; Ashbaugh, 1999; D'Arcy, 2000),

- lower cost of capital (Haller, 2002; Cooker and Hayes, 1992; Ballwieser, 1999),

- avoiding the gap between consolidated and individual reporting, practical and efficiency reasons (Hahn, 2001; Busse von Colbe, 2002),

and the arguments against complete harmonization, particularly considering SMEs:

- cost of providing data as required by IFRS (Bollen, 1995),

- tax accounting (Guenther and Hussein, 1995 and Lamb et al., 1998; Haler, 2002; Street and Larson, 2004),

- different user needs (Page, 1984; Barker and Noonan, 1996; Collis and Jarvis, 2000; Paoloni and Demartini, 1997, also Demartini 2006, 2007/; Riistama and Vehmanen, 2004; Hussey and Hussey, 1997; Chaveau et al., 1996; Friedlob and Plewa, 1992, Knutson and Wichmann, 1984; Lippitt and Oliver, 1983; McMahon, 2001; Haller, 2002; Chazen and Benson, 1978; Harvey and Walton, 1996; John and Healeas, 2000);

- compliance with financial disclosure regulations (Bollen, 1995; Ingram et al., 1977; Robert; Ramsay and Sutcliffe, 1986).

Hagigi (2006, p. 243, 244) summarized pro-s and con-s of differential accounting measurement and disclosure based on previous studies (Nair and Rittenberg, 1983; Jefcoat and Loudel, 1984; Knutson and Wichmann, 1984; Korn, 1984; Stanga and Tiller, 1983; Elsea and McConell, 1987). In favour of differential reporting there are differences in user's needs, access to internal information, complexity of transactions and higher costs for small companies relative to their

Maria-Gabriella Baldarelli, Paola Demartini, Lorena Mosnja-Skare, Paola Paoloni- ACCOUNTING HARMONIZATION FOR SME-S IN EUROPE: SOME REMARKS ON IFRS FOR SME-S AND EMPIRICAL EVIDENCES 
benefits, while against different sets of GAAP, there are fear of reducing the credibility, confusion among the statement users, difficulties of defining the small business, the lack of consistency and comparability. Like Di Pietra, R. (2010) noticed "Within the same European Union (EU) context there are, at least, 4 different set of rules to prepare financial statements. We are facing with a sort of segmentation of the financial statements in respect to the categories to which a firm belongs."

Analyzing the need for accounting standards for SMEs ("Little GAAP"), Morris, P. and Campbell, J. (2006, p. 79), concluded: "What is clear from the Big GAAP-Little GAAP initiatives is that there is a significant demand both in the US and internationally for an alternative form of GAAP for companies that are not publicly traded. The factors driving this demand for a second GAAP are: the needs of users, and the cost of using current GAAP. Moreover, the same authors (p.81) wonder: "Is it really the needs of the users or is it the dissatisfaction of many accounting practitioners with the complex nature of current GAAP? When surveyed, it is that group that finds the greatest "challenge" to "keep current and up-to-date" with GAAP (American Institute of Certified Public Accountants - AICPA Comparisons 52-54). We look forward to seeing continuing activity in both the United States (US) and internationally. We must always remember, whatever the outcome in this debate, what is important is that we meet the fundamental objective of accounting and financial reporting: to provide useful information for decision making."

\section{THE IASB'S PROJECT: IFRS FOR SMES. SOME REMARKS}

\subsection{THE PROJECT HISTORY}

The objective of the IASB project (Delvaille, Ebbers and Saccon, 2004) was to develop an IFRS expressly designed to meet the financial reporting needs of

Maria-Gabriella Baldarelli, Paola Demartini, Lorena Mosnja-Skare, Paola

Paoloni- ACCOUNTING HARMONIZATION FOR SME-S IN EUROPE: SOME REMARKS ON IFRS FOR SME-S AND EMPIRICAL EVIDENCES 
entities that (a) do not have public accountability and (b) publish general purpose financial statements for external users (Evans, Gebhardt, Hoogendoorn, Marton, Di Pietra, Mora, Thinggard, Vehmanen and Wagenhofer, 2005). Examples of such external users include owners who are not involved in managing the business, existing and potential creditors, and credit rating agencies.

In June 2004, the Board issued a Discussion Paper, Preliminary Views on Accounting Standards for Small and Medium-sized Entities, setting out and inviting comments on the Board's preliminary views on the approach to the project. One hundred and twenty responses were received.

The responses to the Discussion Paper showed a clear demand for an IFRS for $S M E s$ and a preference, in many countries, to adopt a global private entity standard rather than locally or regionally developed standards. Hence, the Board decided to remain committed to this project and to develop an exposure draft of an IFRS for SMEs as the next step.

Due to the fact that Discussion Paper did not include proposals for specific financial reporting standards for SMEs, the IASB concluded that it needed further information to assess possible recognition and measurement simplifications. Consequently, in 2005, the Board instructed the staff to develop and publish a questionnaire as a tool to identify issues that should be discussed at those round-table meetings (Staff Questionnaire on Recognition and Measurement Modifications for SMEs).

The responses to the questionnaire were discussed in 2005 and 2006 years and, finally, the final Exposure Draft (ED) of an IFRS for SMEs was published by the IASB for comments on 15 February 2007 (Paoloni, 2007).

In the following table 1, the main ED underpinnings will be briefly analysed in order to highlight later on the different standpoints of the European Financial Reporting Advisory Group (EFRAG).

Maria-Gabriella Baldarelli, Paola Demartini, Lorena Mosnja-Skare, Paola Paoloni- ACCOUNTING HARMONIZATION FOR SME-S IN EUROPE: SOME REMARKS ON IFRS FOR SME-S AND EMPIRICAL EVIDENCES 
TABLE 1 The Exposure Draft's basic underpinnings

\begin{tabular}{|l|}
\hline The size criterion \\
\hline $\begin{array}{l}\text { The Board intends the IFRS for SMEs to be a stand-alone document for a typical private } \\
\text { entity with about } 50 \text { employees. The '50 employees' concept was a guide to the Board in } \\
\text { deciding the content of the standard. It is not intended as a quantified size test for defining a } \\
\text { private entity, though jurisdictions adopting the IFRS for SMEs may add one. }\end{array}$ \\
\hline \\
\hline The users' needs and cost-benefit considerations \\
\hline $\begin{array}{l}\text { The Exposure Draft was developed by extracting the fundamental concepts from the IASB } \\
\text { Framework in the light of users' needs and cost-benefit considerations. }\end{array}$ \\
\hline \\
\hline The modifications of full IFRS \\
\hline $\begin{array}{l}\text { The modifications are of five broad types based on needs of users of private entities' } \\
\text { financial statements and cost-benefit considerations: }\end{array}$ \\
\hline $\begin{array}{l}\text { a. } \\
\text { Topics omitted. Examples: Earnings per share, interim financial reporting, and segment } \\
\text { reporting. }\end{array}$ \\
\hline b. $\begin{array}{l}\text { Only the simpler option included. Examples: No option to revalue property, equipment, } \\
\text { or intangibles; a cost-depreciation model for investment property unless fair value is } \\
\text { readily available without undue cost or effort; no 'corridor approach' for actuarial gains } \\
\text { and losses. }\end{array}$ \\
\hline c. $\begin{array}{l}\text { Recognition and measurement simplifications. For example, amortise goodwill; expense } \\
\text { all borrowing and research and development (R\&D) costs; cost model for associates and } \\
\text { jointly-controlled entities; no available-for-sale or held-to-maturity classes of financial } \\
\text { assets. }\end{array}$ \\
\hline d. $\begin{array}{l}\text { Disclosure reductions. Significantly fewer disclosures are required (roughly } 300 \text { versus } \\
\text { 3,000). }\end{array}$ \\
\hline e. Redrafting in 'plain English' \\
\hline $\begin{array}{l}\text { To further reduce the burden for SMEs, revisions to the IFRS will be limited to once every } \\
\text { three years. }\end{array}$ \\
\hline
\end{tabular}

\section{Source: Authors calculation}

Later on the Board received 162 letters on comment on the ED and began its re-deliberations of the Exposure Draft in March 2008. Furthermore, 116 SMEs from 20 countries participated in 'field testing' by restating their most recent annual financial statements following the proposals in the ED and reporting to the Board on any problems encountered.

In March 2009, the Board concluded that the changes made to the ED "are not of such a nature as to require re-exposure". Thus, the IASB issued an IFRS designed for use by SMEs on the $9^{\text {th }}$ of July 2009.

However, due to the fact that the opinion of EFRAG is influencing in considering a future adoption of IFRS for SMEs by member States of the EU, in the following

Maria-Gabriella Baldarelli, Paola Demartini, Lorena Mosnja-Skare, Paola Paoloni- ACCOUNTING HARMONIZATION FOR SME-S IN EUROPE: SOME REMARKS ON IFRS FOR SME-S AND EMPIRICAL EVIDENCES 
EFRAG basic remarks and objections on the ED will be highlighted, focusing on the above-mentioned matters:

\section{1. size criterion,}

2. users' needs and cost-benefit considerations,

\section{3. modifications of full IFRS.}

\subsection{THE EFRAG BASIC REMARKS}

\subsubsection{THE SIZE CRITERION}

EFRAG has observed that the label "IFRS for SMEs" quite often creates misunderstandings. The label "SME" is widely used internationally to refer to the size of entities in general. The scope of the ED, which excludes all entities, which meet the proposed definition for public accountability, did not refer to size criterion of any kind. Therefore EFRAG recommended that the IASB relabelled this set of standards as "IFRS for NPAE's" (non publicly accountable entities). What it was important to notice also, as it regards to the European context, was that EFRAG believed that the IFRS for SMEs was likely to be suitable for indeed quite a large range of entities (see Fig. 1).

Large entities, on one side of the spectrum, may at some stage in their development, decide to opt for full IFRS for example in order to be comparable to some of their competitors who are listed companies and report under IFRS, or because they enter into very sophisticated transactions that, in their view, would be best accounted for under IFRS, or because some of the users of their financial reporting (banks or rating agencies) require it. Until such circumstances arise, the IFRS for SMEs is likely to adequately serve their financial statement users' needs.

On the other side of the spectrum, jurisdictions may decide to exempt very small entities from issuing general purpose financial statements, altogether, or to derive from the IFRS for SMEs a further simplified set of accounting standards

Maria-Gabriella Baldarelli, Paola Demartini, Lorena Mosnja-Skare, Paola Paoloni- ACCOUNTING HARMONIZATION FOR SME-S IN EUROPE: SOME REMARKS ON IFRS FOR SME-S AND EMPIRICAL EVIDENCES 
applicable to micros, that they would publish as their national GAAP for micros. At this end of the spectrum, such decisions may be made on very stringent cost/benefit trade-offs.

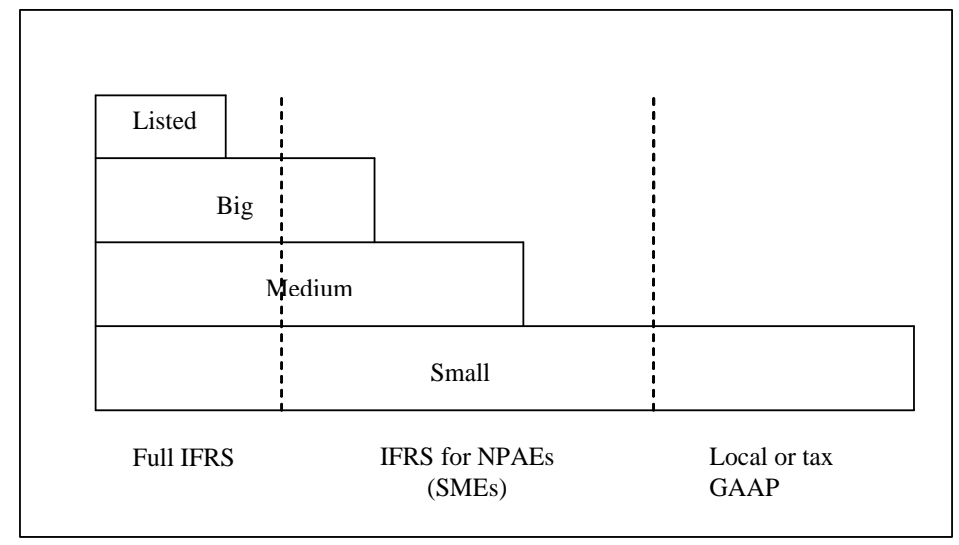

FIGURE 1 The potential scope of IFRS for SMEs in the European context

Source: our synthesis from EFRAG Comment letter to ED

Consequently, the EFRAG believed that the reference to 50 employees should be eliminated from the basis for conclusions of the ED because:

1. a number of employees is not, in itself, a relevant depiction of business complexity or of economic significance;

2. 50 employees may vary in significance from one economic environment to the next.

\subsubsection{THE USERS' NEEDS AND COST-BENEFIT CONSIDERA- TIONS}

In its ED basis for conclusions, the IASB acknowledged that users' needs (Page, 1984; Carsberg et al.,1985; Paoloni and Demartini,1997; Dugdale, Hussey and Jarvis, 1998; Moneva et al.,2000; Demartini et al.,2003; Carsberg et al.,1985) of

Maria-Gabriella Baldarelli, Paola Demartini, Lorena Mosnja-Skare, Paola Paoloni- ACCOUNTING HARMONIZATION FOR SME-S IN EUROPE: SOME REMARKS ON IFRS FOR SME-S AND EMPIRICAL EVIDENCES 
NPAEs were different from those of users of financial statements of publicly accountable entities. The IASB also clearly indicated that these differences needed to be reflected in different recognition and measurement principles. However EFRAG believed that these conclusions had not been fully taken into account in the decisions made by the IASB.

For example, the IASB acknowledged that users of financial statements of SMEs were less interested in value and more interested in how the entity might be able to meet its obligations when due. However the IASB very quickly asserted that in particular no change in either recognition or measurement was required in order to fit these differences in user needs.

As a consequence, EFRAG recommended that a further analysis should be conducted and more changes to the existing measurement requirements might be necessary in order to better serve the needs of users'.

A bank or a supplier, for example, want to assess whether the entity's financial position is strong enough to justify the risk of lending money or of supplying goods. The typical small and medium-sized entity has relatively few non-manager shareholders compared to listed entities, and those shareholders' investments tend to be for a far longer term. As a result, measurement based on market values have less relevance to users of SME financial statements when applied to assets which the entity does not have the ability to realize or to liabilities that the entity cannot transfer. Finally, there is a great interest amongst users of SME financial statements on the entity's ability to generate positive cash-flows in the short and medium-term to meet liabilities as they fall due.

\subsubsection{THE MODIFICATIONS OF FULL IFRS}

Users of SME financial statements might be less sophisticated than users of the listed entity financial statements, because the users tend generally not to include capital market analysts, the credit-rating agencies, or employee representative groups (such as Unions). As a result, SME financial statements need to be easily understandable and every unnecessary complexity or variety in accounting treatments must be eliminated.

Therefore in EFRAG point of view, an accounting standard is simple if it is

Maria-Gabriella Baldarelli, Paola Demartini, Lorena Mosnja-Skare, Paola Paoloni- ACCOUNTING HARMONIZATION FOR SME-S IN EUROPE: SOME REMARKS ON IFRS FOR SME-S AND EMPIRICAL EVIDENCES 
easy to understand and simple to implement. Accounting requirements should vary only where there are substantial differences to capture. e.g. there is no need to have several different definitions of cost, or different ways of applying the revaluation model.

The IASB, of course, had put forward in its ED some simplifications in the recognition and measurement. However EFRAG believed that further simplifications could be made, while remaining consistent with the IFRS conceptual framework. These simplifications included, inter alia:

1. reinstating the amortisation of goodwill and other intangible assets,

2. promulgating only one cost model and one revaluation model for nonfinancial assets,

3. eliminating the reference to the name "fair value",

4. and eliminating the recognition of equity settled share-based payments.

In EFRAG's view, simplifications on financial assets and liabilities were inadequate and resulted in requirements, which were still quite difficult to understand, and to implement. Therefore, even if EFRAG agreed with the development of an IFRS for not publicly-accountable entities, the content of the standard was not yet satisfactory, if one considers the European economic pattern, made of small and micro enterprises needing to avoid accounting burdens. Even in this case, the missing concern was still the analysis of the users' needs.

\subsubsection{A COMPATIBILITY ANALYSIS OF IFRS FOR SMES AND THE EU ACCOUNTING DIRECTIVES}

EFRAG has also performed compatibility analysis of IFRS for SMEs and the EU Accounting Directives in May 2010 to identify the IFRS for SMEs treatments not permitted by Directives. Here are the inconsistencies found by EFRAG (A Letter to European Commission - EC), listed below:

Maria-Gabriella Baldarelli, Paola Demartini, Lorena Mosnja-Skare, Paola Paoloni- ACCOUNTING HARMONIZATION FOR SME-S IN EUROPE: SOME REMARKS ON IFRS FOR SME-S AND EMPIRICAL EVIDENCES 
1. The prohibition to present or describe any items of income and expense as "extraordinary items" in the statement of comprehensive income (or in the income statement, if presented) or in the note.

2. The requirement to measure financial instruments within the scope of section 12 of the IFRS for SMEs (non-basic financial instruments) at fair value (IFRS for SMEs par. 12.7 and 12.8). (Par. 11.2 of the IFRS for SMEs includes an option for entities to choose to apply the recognition and measurement provisions of IAS 39 Financial Instruments: Recognition and Measurement. As the option does not refer to a specific version of IAS 39, EFRAG has not been able to assess whether this option would be compatible with the EU Accounting Directives or not. Accordingly, EFRAG has disregarded the option when assessing whether or not the requirements of the IFRS for SMEs regarding financial instruments are compatible with the EU Accounting Directives or not.)

3. The requirement to presume the useful life of goodwill to be ten years if an entity is unable to make a reliable estimate of the useful life (IFRS for SMEs par. 19.23)

4. The requirement to recognize immediately in profit or loss any negative goodwill (IFRS for SMEs par. 19.24)

5. The requirement to present the amount receivable from equity instruments issued before the entity receives the cash or other resources, as an offset to equity and not as an asset (IFRS for SMEs par. 22.7(a))

6. The prohibition to reverse an impairment loss recognized for goodwill (IFRS for SMEs par. 27.28).

According to the research performed by the EC (EC Summary Report: of the responses received to the Commission's Consultation on IFRS for SMEs, 2010), 13 member states (Cyprus, Czech Republic, Denmark, Estonia, Greece, Spain, Ireland, Malta, Netherlands, Poland, Portugal, Sweden, United Kingdom) find the IFRS for SMEs feasible for application, while 9 member states (Austria,

Maria-Gabriella Baldarelli, Paola Demartini, Lorena Mosnja-Skare, Paola Paoloni- ACCOUNTING HARMONIZATION FOR SME-S IN EUROPE: SOME REMARKS ON IFRS FOR SME-S AND EMPIRICAL EVIDENCES 
Belgium, Bulgaria, Germany, Finland, France, Italy, Slovakia, Slovenia) don't consider them applicable in financial reporting of their SMEs.

Among the European Accounting Association Financial Reporting Standards Committee - EAA FRSC's comments (Evans, L., 2010), the following question listed is very important, not only for developing, but also for transitional economies: "If the IFRS for SMEs is of greatest relevance to developing economies, are these economies' needs and circumstances considered?" Some comparisons between IFRS for SMEs and CFRS (Croatian Financial Reporting Standards) are presented in the next chapter.

\section{ACCOUNTING STANDARDS FOR SMES IN CROATIA}

The accounting harmonization in Europe and worldwide has also been reflecting on Croatian SMEs that were obliged to implement international standards for 15 years.

\subsection{ACCOUNTING STANDARDS IN CROATIA: FROM IFRS TO CFRS}

In the period 1993-2010, there were three Accounting Acts that regulated the accounting standards implementation. The Act in force from January 1993 required all the companies to use IAS, independently of their size or quotation. The Act from 2005 required IFRS to be implemented in listed companies or those preparing to go public and in large enterprises, while SMEs could choose between full IFRS or the standards adopted by Croatian Financial Reporting Standards Board (CFRSB) ${ }^{1}$.

Still, de facto implementation of IFRS/IASs was poor due to the overburden of non-public interest companies, also to the weak enforcement mechanism, late

\footnotetext{
${ }^{1}$ An expert body established in March 2006, appointed by the Government to translate, interpret, approve and publish IFRSs.
}

Maria-Gabriella Baldarelli, Paola Demartini, Lorena Mosnja-Skare, Paola Paoloni- ACCOUNTING HARMONIZATION FOR SME-S IN EUROPE: SOME REMARKS ON IFRS FOR SME-S AND EMPIRICAL EVIDENCES 
and improper IASs translations. According to the empirical analysis of accounting standards implementation in Croatian SMEs (Baldarelli, M.G., Demartini, P., Mošnja-Škare, L., 2007: 137-141), in 44\% of cases, financial statements in accordance with the regulation in that period, were not considered to meet the users' needs; in $30 \%$ of cases accounting was considered just like the mandatory burden; in $22 \%$ of cases the financial statements and accounting information were considered as too complex to be understandable and user-friendly.

Searching for the solution, there were four options considered for Croatian SMEs (Tadijančević, S., 2006, p. 25):

1. reconciliation of IASs 2000 published in the Official Gazette with IV. and VII. European Directives (ED),

2. direct implementation of IV. and VII. ED,

3. IFRS implementation for all entities independently of their size and public interest,

4. CFRS introduction.

The latest Act, in force from January 2008 has introduced CFRS. All listed companies and those preparing to go public as well as large enterprises are required to use IFRS, while CFRS are required for all other enterprises. Large enterprises are those that meet two of the three criteria: total assets higher than HRK (hrvatska kuna) 130 million, revenues higher than HRK 260 million, employing more than 250 employees. All financial institutions and other companies as required by financial sector supervisory authorities are considered as large enterprises.

\subsection{CROATIAN FINANCIAL REPORTING STANDARDS}

CFRS were approved by CFRSB on February 28, 2008. They are founded on Croatian accounting practices, and are in line with 4th and 7th ED and IFRS. Founding the CFRS on IFRS is explained by fifteen-year experiences of Croatian entities in IASs implementation, consolidation needs, income tax purposes and

Maria-Gabriella Baldarelli, Paola Demartini, Lorena Mosnja-Skare, Paola Paoloni- ACCOUNTING HARMONIZATION FOR SME-S IN EUROPE: SOME REMARKS ON IFRS FOR SME-S AND EMPIRICAL EVIDENCES 
by the possibility of easier transfer to full IFRS. Alignment with EDs is necessary considering Croatian mission to enter the EU.

CFRS are simpler and shorter then IFRS, intended to follow the needs of SMEs. They consist of:

1. the Framework for the CFRS application that covers: approach, basic assumptions and principles, accounting categories definition, measurement and recognition of financial reports' items, CFRS list, first adoption and the date of introduction.

2. CFRS 1-17 with introduction, definition, contents, recognition, measurement, derecognition and disclosures for every standard, and Glossary in addition. (Gulin, D., ed., 2008, p. 1-3).

\subsubsection{CFRS AND IFRS FOR SMES}

IFRS for SMEs developments will reflect to CFRS since both sets of standards are intended for the same group of enterprises (Gulin, D., ed., 2008, p.4). National regulators will compare the solutions offered by both sets, having in mind that many Croatian SMEs participate in foreign trade, or have credit arrangements with foreign lenders where comparable financial reports are needed. SMEs participate with $40 \%$ in Croatian exports, employing $65 \%$ of employees, making $44 \%$ of GDP and presenting $99 \%$ of the total number of registered enterprises (According to Croatian Employers' Association-SMEs Association, 2008).

CFRS are shorter (17 standards / CFRS - 35 sections / IFRS for SMEs) and they are structured following the balance sheet items, while sometimes there is more than one IFRS for SMEs treating particular item. IFRS for SMEs comprise separate sections for e.g. each financial report separately, for investments in subsidiaries, joint ventures, business combinations, leases, provisions and contingencies, government grants, borrowing costs, share-based payment, impairments, employee benefits, income tax, related party disclosures, hyperinflation, foreign currency translation. These topics are either imbedded in other standards, either exempted from CFRS.

Maria-Gabriella Baldarelli, Paola Demartini, Lorena Mosnja-Skare, Paola Paoloni- ACCOUNTING HARMONIZATION FOR SME-S IN EUROPE: SOME REMARKS ON IFRS FOR SME-S AND EMPIRICAL EVIDENCES 
Both set of standards cover the whole set of financial reports: balance sheet, income statement, cash flows statement, statement of changes in equity and notes (CFRS); statement of financial position, statement of comprehensive income and income statement, statement of changes in equity and statement of comprehensive income and retained earnings, statement of cash flows, notes to the financial statements (IFRS for SMEs). Croatian Accounting Act doesn't require small enterprises to prepare the cash flows statement and statement of changes in equity, but other reports are of the same structure and contents as for medium and large enterprises. Both sets of standards allow direct or indirect method for cash flows statement. Income statement is founded on the total costs method; expenses are presented by nature according to CFRS and by nature or function according to IFRS for SMEs. Other-extraordinary items take part in the income statement under CFRS.

CFRS allow the revaluation for measurement after initial recognition of tangible and intangible assets, capitalization of interests and development expenses, what is not allowed under IFRS for SMEs.

\subsubsection{CFRS IMPLEMENTATION: SOME EMPIRICAL OBSER- VATIONS}

After describing the way towards CFRS, we are going to catch some reflections their introduction had in the real practice. Without the intention to derive representative conclusions for the whole Croatian economy, what would require broader systematic research and larger sample, we present some empirical observations based on the research before and after CFRS introduction.

According to the empirical research (Klikovac, A., 2006), 59\% of the examined Croatian SMEs found that CFRS should be introduced, $69 \%$ of them considered IFRS for SMEs to be suitable once they would be published (this research was performed 3 years before the IFRS for SMEs were launched). They explained such attitude by the fact that they already had some experiences with IAS implementation, they also considered IFRS for SMEs could be feasible to their needs, allowing easier transfer to full IFRS as the business grew, and finally, due to harmonization reasons, they thought IFRS for SMEs would be widely

Maria-Gabriella Baldarelli, Paola Demartini, Lorena Mosnja-Skare, Paola Paoloni- ACCOUNTING HARMONIZATION FOR SME-S IN EUROPE: SOME REMARKS ON IFRS FOR SME-S AND EMPIRICAL EVIDENCES 
TABLE 3 Standards set preferences

\begin{tabular}{cc}
\hline \hline We prefer to continue implementing IFRS instead of national standards (CFRS) & 5 \\
\hline IFRS for SMEs should be implemented instead of national standards (CFRS) & $28 \%$ \\
& 2 \\
We find CFRS more feasible to apply than IFRS & $11 \%$ \\
& 5 \\
We find CFRS are not in accordance with our expectations and needs and further & $28 \%$ \\
upgrading is needed & $63 \%$ \\
\hline \hline
\end{tabular}

\section{Source: author's calculation}

Similarly to Klikovac's research, there were $61 \%$ of examinees voting for CFRS, but $33 \%$ of the examinees found them in disaccordance with their needs implicating the need for further upgrading. There was a low share of those voting for IFRS for SMEs comparing to Klikovac's research, probably because her research was performed before, while this research was performed after the CFRS and IFRS for SMEs were introduced. Once Croatia has introduced CFRS in 2008, it would be costly to replace them by another standards set and the examinees were better acquainted with CFRS than with IFRS for SMEs. The association between the standards set preference and the enterprise's size (small versus medium) as well as the enterprise's number of employees, was not statistically significant. Neither of the examinees with V. or VI. education degree voted for IFRS or IFRS for SMEs. Certified accountants and the ones with VII. degree were obviously better acquainted with international standards.

Most of the examinees found the educational support in CFRS implementation to be well established, but $30 \%$ of examinees still didn't find it helpful enough. Also, most of them contact advisors in accounting associations when some problems in CFRS implementation are encountered, pointing out the crucial role of accounting associations in the accounting developments in Croatia.

Maria-Gabriella Baldarelli, Paola Demartini, Lorena Mosnja-Skare, Paola Paoloni- ACCOUNTING HARMONIZATION FOR SME-S IN EUROPE: SOME REMARKS ON IFRS FOR SME-S AND EMPIRICAL EVIDENCES 
TABLE 4 Consulting for CFRS implementation problems solving

\begin{tabular}{cc}
\hline \hline other accountants - colleagues & 10 \\
& $50 \%$ \\
\hline private consultants & 6 \\
& $30 \%$ \\
accounting associations' consultants & 12 \\
auditors & $60 \%$ \\
& 8 \\
academic institutions & $40 \%$ \\
& 0 \\
other (brief courses, Internet, trade & $0 \%$ \\
journals, etc.) & 2 \\
& $10 \%$ \\
\hline \hline
\end{tabular}

Note: examinees could select multiple answers.

Source: author's calculation.

Looking for IFRS as needed in addition to the topics covered by CFRS, $79 \%$ of examinees didn't need any additional IFRS, while $21 \%$ of the examinees would need some IFRS like IAS 34, IAS 19. CFRS were mostly considered to be sufficient enough, not requiring to be broadened by additional IFRS. The relations between the need for the additional IFRS/IAS and the standards set preference, as well as the enterprise's size and the examinees' education were not proven to be statistically significant.

On the other hand, CFRS that were not implemented by examinees were as follows: CFRS 2 (not implemented by $6,32 \%$ examinees), CFRS 4 (2, 11\%), CFRS 7 (3, 16\%), CFRS 8 (2, 11\%), CFRS 9 (2, 11\%), CFRS 17 (15, 79\%).

TABLE 5 CFRS implementation and the standards set preference

\begin{tabular}{ccc}
\hline \hline $\begin{array}{c}\text { STANDARDS SET } \\
\text { PREFERENCE }\end{array}$ & ALL CFRS NEEDED & SOME CFRS MARKED AS \\
OUT OF NEED
\end{tabular}

Source: author's calculation.

Maria-Gabriella Baldarelli, Paola Demartini, Lorena Mosnja-Skare, Paola Paoloni- ACCOUNTING HARMONIZATION FOR SME-S IN EUROPE: SOME REMARKS ON IFRS FOR SME-S AND EMPIRICAL EVIDENCES 
Some CFRS were marked as out of need mostly by the examinees whose expectations were not met by current set of CFRS and by the ones voted for IFRS. This relation is statistically significant (Fisher's exact test, $\mathrm{p}=0.0474$ ). The enterprise's size, number of employees, examinees' education level were not of the statistically significant influence.

The presented results confirmed that CFRS were accepted by all not-listed Croatian SMEs examined, but their preferences regarding the standards set feasible to their needs were still different. Still $33 \%$ of the examinees found CFRS didn't meet their needs.

Accounting harmonization has been progressing, also among EU countries and EU harmonization flows are necessary to be followed considering Croatian mission to enter the EU. CFRS will be improving, following the changes at European and global level. In case EU introduces IFRS for SMEs as obligatory for member States, that will probably bring towards replacing CFRS by IFRS for SMEs (Žager, K., Smrekar, N., 2010, p.38).

On the other hand, Croatian experiences present an interesting developmental path considering current trends in EU and wider towards global standards adoption.

In order to achieve harmonization goals, as well as for the SMEs, it is advisable to follow the words of John Hegarty, (World Bank, ROSC, 2005): "to make explicit the implicit assumptions on legal, institutional and political preconditions that form the basis of international standards." Some suggestions in that direction, upon future research on IFRS for SMEs are provided.

\section{SOME SUGGESTIONS AND BASIC REMARKS ON FUTURE IFRS FOR SMES DEVELOP- MENTS}

Some articles tried to explain why IFRS for SMEs didn't have so success as expected (Di Pietra et al., 2008). Considering one of the main reasons only the contingent situation and plaintive not so much empirical research results about

Maria-Gabriella Baldarelli, Paola Demartini, Lorena Mosnja-Skare, Paola

Paoloni- ACCOUNTING HARMONIZATION FOR SME-S IN EUROPE: SOME REMARKS ON IFRS FOR SME-S AND EMPIRICAL EVIDENCES 


\section{SMEs.}

We want to suggest some future dimensions and challenges about accounting harmonization for SMEs and how IFRS can contribute to this process. We base our analysis on the idea that SMEs are directly deeply involved in a world in profound transformation. We will examine some dimensions that in our opinion must be considered and then we'll try to suggest some reflections about IFRS for SMEs.

The first dimension is about anthropological factors that are at the base of EU entity values and accounting results too. The second is about the SMEs attitude to create and above all to consolidate formal and informal relationships and networks to survive in a global competitive world. Then it comes the creation of relational capital that must be considered as an important part of SMEs values and results and how to develop and to measure it.

About culture, according to the researchers, there are institutional, environmental, market and taxation differences (Hofstede, 1980; Nobes, 1992; Belkaoui, 1985; Gray, 1988; Baldarelli, M.G., Demartini, P., Mošnja-Škare, L., 2007:35), although it should not be forgotten that Europe had a cultural phenomenon. This cultural phenomenon is profoundly rooted in its already present values. These values contributed in a large way to the formation of the basic underground that form Humus indestructible, on which one can count on even for the harmonization concerning SMEs (Di Pietra and Landi, 2007).

The tendency is for an increasing importance of the IFRS, followed by an approach of IFRS towards US-GAAP with a comprehensible consequence for European companies.

This will create difficulty where the financial statement needs to be written with respect to the law, where the information system is directly and exclusively for investors, conflicting with a tradition that especially favors owners and creditors. So we see that the establishment of national board that are be able to harmonize IFRS and national culture can solve this problem especially for SMEs that require more transparency and simplicity.

The second important point is that SMEs are often an integral part of a network and so must consider stakeholders network needs, that we may define "internal"

Maria-Gabriella Baldarelli, Paola Demartini, Lorena Mosnja-Skare, Paola Paoloni- ACCOUNTING HARMONIZATION FOR SME-S IN EUROPE: SOME REMARKS ON IFRS FOR SME-S AND EMPIRICAL EVIDENCES 
that have requirements questions about adequate economic and financial results knowledge (Lorenzoni, 1992; Lohrke, Kreiser, Weaver, 2006).

Intra-company ${ }^{3}$ relations have evolved through time becoming almost exclusively instrumental to the economic benefits and to the reaching of maximum profit for involved profit-making companies.

Besides, the word that often comes back to us in one of the most enlightening writings on the subject of business aggregates is that of "correlation" and interdependence (Riparbelli, 1962; Rener, Arino, Mellewight, 2006), especially this latter word seems to characterise our times and prepare us for the future.

Indeed, interdependence for profit-making companies may not only be intended as specificity, which concerns economic convenience, but also that "social" one. Thus the pervasive importance of SMEs taking part in networks let us to reflect about their economic role strictly accompanied by their social and environmental one. In the latest case we must underline enterprise behaviour in the respect of several national and foreign stakeholders (Freeman, 1984, Matacena, 1984). From that derives that modern enterprise is defined by same scholars as "global" and by others "social", or "responsible" too. This type of enterprise must have some qualities that in the past weren't required. One of that is to reply to numerous stakeholders' requirements, stakeholders that have their international nature.

Finally, recent economic trend to underline relational goods needs (Gui, Sugden, 2005) in finding in SMEs major availability to develop them, because, especially in this period of crisis, without them it's impossible to survive in the long period. Only if SMEs have cooperation propensity and activating relational goods, they can survive and continue to produce. Relational goods are recognized as relational capital that is one of the most important intangible assets (Lev, 2003). Regarding the context described above, what are the answers that may derive to improve IFRS for SMEs?

\footnotetext{
${ }^{3}$ Corporate relations are fundamental in this sense: "Company life is essentially one of "relationships"... If company life is essentially one of relationships, there is no-one who does not see the high scientific and practical utility of investigations on the relationships which are established between companies themselves and between companies and the external economic environment where they work" (Riparbelli, 1962, p.5).
}

Maria-Gabriella Baldarelli, Paola Demartini, Lorena Mosnja-Skare, Paola Paoloni- ACCOUNTING HARMONIZATION FOR SME-S IN EUROPE: SOME REMARKS ON IFRS FOR SME-S AND EMPIRICAL EVIDENCES 
By the normative point of view financial statement has to be oriented to communicate information exclusively to "a wider range of economic decision making users". So the message taken by SMEs accounting harmonization process is globally oriented to investors and in any case to economic decision makers, even if, as we will see onward, we include in this field more important elements, such as the interim reporting and environmental and social integrative accounting and reporting (Gray, Owen, Adams, 2000). This wonder us about SMEs' needs, where financial statement information system is already complicated by tributary low and leave less space to other integrations.

In conclusion, accounting harmonization is a very important occasion combined to the globalization process but IASB is far from considering all different important fields that we described above.

\section{REFERENCES}

Baldarelli, M.G., Santi, M., Signori S. (2005): Chiacchierando con E. Freeman, Non Profit, 1.

Baldarelli, M.G., Demartini, P., Mošnja-Škare, L. (2007): International Accounting Standards for SMEs: Empirical Evidences from SMEs in a Country in Transition and a Developed Country Facing New Challenges, Juraj Dobrila University of Pula - Mikrorad, Zagreb.

Belkaoui, A. (1983): Economic, Political and Civic Indicators and Reporting and Disclosure Adequacy: Empirical Investigation, Journal of Accounting and Public Policy, 2: 3, pp. 207-19.

Briloff, A. (1979): Truth about corporate accounting, Harper and Row, N.Y.

Capodaglio, G.; Baldarelli, M.G.(eds) (2006): L'armonizzazione dei principi contabili in Europa. Quali "regole" per le piccole e medie imprese?, Roma, RIREA.

Carsberg, B.V., Page, M.J., Sindell A.J.and Waring, I.D. (1985): Small Company Financial Reporting, Prentice Hall International- ICAEW, London.

Maria-Gabriella Baldarelli, Paola Demartini, Lorena Mosnja-Skare, Paola Paoloni- ACCOUNTING HARMONIZATION FOR SME-S IN EUROPE: SOME REMARKS ON IFRS FOR SME-S AND EMPIRICAL EVIDENCES 
Collis J., Jarvis R. (2000): How Owner-managers Use Accounts, The Institute of Chartered Accountants in England \& Wales.

Croatian Accounting Acts 1992, 2005, 2007 Official Gazettes 90/92, 146/05, 109/07.

Croatian Financial Reporting Standards Board - decisions (Official Gazettes 61/06, 122/06, 140/06, 30/08, 130/08, 137/08, 4/09, 29/09, 136/09, 8/10, 18/10, 27/10, decisions on May 10, 2010).

Delvaille, P., Ebbers, G., Saccon, Ch.(2004): International Financial Reporting Convergencies: evidence from three continental European countries, Accounting in Europe, Vol 2., pp. 137-164.

Demartini, P. (2006): Accounting Harmonisation for European Small Business, in: Capodaglio, G., Baldarelli, M.G. (eds.), L'armonizzazione dei principi contabili in Europa. "Quali regole" per le piccole e medie imprese?, Rimini, December, 2005, Casa Editrice della Rivista Italiana di Ragioneria e di Economia Aziendale, Roma, pp. 223-240.

Di Pietra, R., Evans L., Chevy J., Cisi M., Eierle B., Jarvis R., on behalf of the European accounting association's financial reporting standards committee (2008): Comment on the IASB's Exposure Draft "IFRS for SMEs", Accounting in Europe, Vol. 5, pp. 27-45.

Di Pietra, R. (2010): IFRS for SMEs and EU Accounting Directives Modernization, EAA 33rd Annual Congress, Istanbul, May 2010.

Dugdale, D., Hussey, J. and Jarvis, R. (1998): Regulatory relaxation and the role of small company annual reports in the UK, paper presented at the Workshop on Accounting Regulation, Siena, 5-7 March.

Eierle, B. (2010): The Research Landscape: Research in SME Financial Reporting, EAA 33rd Annual Congress, Istanbul, May 2010.

EFRAG: A letter to the European Commission specifying the requirements of the IFRS for SMEs that has been assessed to be incompatible with the EU Accounting Directives. http://www.efrag.org/news/detail.asp?id=548 (accessed 28 September 2010)

Evans L., Gebhardt G., Hoogendoorn M., Marton J., Di Pietra R., Mora A., Thinggard F., Vehmanen P. and Wagenhofer A. (2005): Problems and op-

Maria-Gabriella Baldarelli, Paola Demartini, Lorena Mosnja-Skare, Paola Paoloni- ACCOUNTING HARMONIZATION FOR SME-S IN EUROPE: SOME REMARKS ON IFRS FOR SME-S AND EMPIRICAL EVIDENCES 
portunities of an IFRS for SMEs. The EAA FRSC's Comment on the IASB's Discussion Paper, Accounting in Europe, 2: 23-45.

Evans, L. (2010): Reporting for SMEs: European Research Contributions, EAA 22rd Annual Congress, Istanbul, May 2010.

Freeman, R. E. (1984): Strategic Management: a stakeholder approach, Pitman, Boston.

Gray, R., Owen D , Adams C.(2000): Accounting and accountability. Changes and challenges in corporate social and environmental reporting, Prentice Hall Europe, London, UK.(I ed. 1996).

Gray, S.J. (1988): Towards a theory of cultural influence on the development of accounting systems internationally, Abacus, March.

Gui, B., Sugden R. (eds.) (2005): Economics and social interactions. Accounting for interpersonal relations, Cambridge University Press, Cambridge.

Gulin, D., ed. (2008): Croatian Financial Reporting Standards Implementation, Croatian Association of Accountants and Financial Experts, Zagreb.

Hagigi, M. (2006): Accounting Disclosure: Small Versus Large Companies, in: Capodaglio, G., Baldarelli, M.G. (edts.) L'armonizzazione dei principi contabili in Europa. "Quali regole" per le piccole e medie imprese?, Rimini, December, 2005, Casa Editrice della Rivista Italiana di Ragioneria e di Economia Aziendale, Roma, pp, 241-259.

Hofstede, G. (1980); Culture's consequences, Sage Publication, Beverly Hills. Hegarty, J.: International accounting and auditing standards implementation, experiences under the ROSC program, World Bank Group, presentation December 20, 2005.

Hutchinson, P.J. and Ray J. (1986): Surviving the Financial Stress of Small Enterprise Growth, in J. Curran, J. Stanworth and D. Watkins (eds.), The survival of the Small Firm. Volume 1: The Economics of Survival and Entrepreneurship, Gower Publishing, Aldershot (UK).

Kirby, D. A., Najak B. and Greene F. (1998): Accounting for growth: Ways accountants can add value to small businesses, ICAEW, London.

Maria-Gabriella Baldarelli, Paola Demartini, Lorena Mosnja-Skare, Paola Paoloni- ACCOUNTING HARMONIZATION FOR SME-S IN EUROPE: SOME REMARKS ON IFRS FOR SME-S AND EMPIRICAL EVIDENCES 
Klikovac, A. (2006): The influence of financial reporting harmonization in EU upon financial reporting in the Republic of Croatia, master thesis, Zagreb.

Lev, B. (2003): Intangibles, Milano, ETAS.

Lohrke, F., Kreiser M. P., Weaver K.M. (2006): The influence of current firm performance on future SME alliance formation intentions: a six country study, Journal of Business Research, 59, pp. 19-27.

Lorenzoni, G. (ed.) (1992): Accordi, reti e vantaggio competitivo. Le innovazioni nell'economia dell'impresa e negli assetti organizzativi, Etas, Milano.

Matacena, A.(1984): Impresa e ambiente. Il " bilancio sociale", Bologna, CLUEB

Mc Mahon, R.G.P. (1999): Modelling the Extent of Financial Reporting Practices amongst Australian Manufacturing SMEs, Small Business Economics, 13, pp. 81-96.

Mc Mahon, R.G.P. and Davies, L.G. (1994): Financial Reporting and Analysis Practices in Small Enterprises: their Association with Growth Rate and Financial Performance, Journal of Small Business Management, January.

Morris, P., Campbell, J. (2006): Big GAAP-Little GAAP - Does OneSize-Fits-All Still Work?, Journal of Business $\&$ Economics Research Vol. 4, No. 5, May 2006, pp. 73-82.

Nobes, C. (1992): International classification of financial reporting, 2nd edition, Routledge, London.

Page, M.J. (1984): Corporate Financial Reporting and the Small Independent Company, Accounting and Business Research, Summer.

Paoloni, M., Demartini, P. (1997): Small company financial reporting: users and information needs, paper presented at the 2oth Annual Congress of the EAA, Graz (Austria).

Paoloni, P. (2007): Il bilancio delle piccolo imprese nell prospettiva internazionale. Il progetto IASB Internatinal Accounting Standards for SMEs, Giappichelli, Torino.

Maria-Gabriella Baldarelli, Paola Demartini, Lorena Mosnja-Skare, Paola Paoloni- ACCOUNTING HARMONIZATION FOR SME-S IN EUROPE: SOME REMARKS ON IFRS FOR SME-S AND EMPIRICAL EVIDENCES 
Paoloni, M. and Demartini, P. (2002): The BIG GAAP/LITTLE GAAP debate: a European view, paper presented at the 2nd International Workshop on Accounting and Regulation (Siena), and published on Piccola Impresa/Small Business, No. 2.

Paoloni, M., Demartini, P., Moneva, J.M. and Cuellar, B. (1999): Analysis of the accounting for small and medium sized firms in the European Union: a management view, paper presented at the XXII Annual Congress of the EAA, Bordeaux, (France), April.

Rener, J.J., Arino, A., Mellewight, Th. (2006): Enterprise neutral alliances as contractual forms, Journal of business venturing, No. 21, pp. 306-325.

Riparbelli A. (1962): Correlazioni e interdipendenze tra organismi aziendali, Pisa, Curzi.

Tadijančević, S. (2006): The Work of CFRSB, Accounting and Finance, No. 11, p. 25.

Veerle, V. (2005): The current state of accounting harmonization: impediments to and benefits from harmonization, working paper D/2005/7012/40, Department of Accountancy and Corporate Finance, Ghent University August 2005, 2005/322.

Žager, K., Smrekar, N. (2010): Promjene regulative financijskog izvještavanja u EU i utjecaj na izvještavanje u RH, in Računovdostvo i financije, No. 7, pp. 35-40.

Maria-Gabriella Baldarelli, Paola Demartini, Lorena Mosnja-Skare, Paola Paoloni- ACCOUNTING HARMONIZATION FOR SME-S IN EUROPE: SOME REMARKS ON IFRS FOR SME-S AND EMPIRICAL EVIDENCES 